\title{
Have school counselors assessed students' anxiety?
}

\author{
Nur Sholehah Dian Saputri ${ }^{1}$, Rita Eka Izzaty ${ }^{2} \&$ Heri Retnawati $^{3}$ \\ ${ }^{123}$ Universitas Negeri Yogyakarta, Indonesia \\ ${ }^{*}$ Corresponding author, $\equiv$ e-mail: nursholehah.2018@student.uny.ac.id
}

\begin{abstract}
Anxiety needs to be assessed and reduced so that it does not interfere with the mission of adolescent development. Guidance and counseling services in formal education must be provided based on the assessment of needs, one of which is in dealing with anxiety. This study was qualitative research with a type of phenomenology. The data related to the implementation of anxiety assessment were collected using interviews and observations. The participants were 15 Senior High School counselors in Yogyakarta. The data analysis was conducted using qualitative data analysis. The results of the study showed that there were still many school counselors who had not deeply assessed students' anxiety. There were still school counselors who experienced obstacles in assessing students' anxiety, such as regarding the time, analytical skills, students' openness problems, and there were no instruments that could be applied easily.
\end{abstract}

Keywords: assessment, students' anxiety, school counselor

How to Cite: Saputri, N., Izzaty, R., \& Retnawati, H. (2019). Have school counselors assessed students' anxiety?. COUNS-EDU: The International Journal of Counseling and Education, 4(4), 148-156. DOI:http://.doi.org/10.23916/ 0020190424840

This is an open access article distributed under the Creative Commons Attribution License, which permits unrestricted use, distribution, and reproduction in any medium, provided the original work is properly cited. (C)2019 by author.

\section{Introduction}

Adolescence is a transitional period or natural transition of human life span that bridges childhood and adulthood (Santrock, 2012). During this period, adolescents experience several significant changes in various matters, including physical, mental, and emotional changes of the child. Khemka \& Rathod (2016) stated that adolescence is a period of internal conflict, psychological balance, and uncertain behavior. Adolescents fight different life pressures ranging from terrible life events, constant tension, and everyday problems (Sharma; 2017).

Another problem that might occur is anxiety. Anxiety is a heterogeneous disorder that has different etiologies and outcomes. Furthermore, anxiety has different physiological characteristics (Wiedemann; 2015). This is in accordance with Dawood (2016) who defined anxiety as an unwanted and unclear feeling when someone predicts a dangerous situation. Extreme levels of anxiety will influence an individual's mental and physical health and also have a negative effect on their personal, social, family, work, and educational performance (Dawood; 2016). High levels of anxiety resulted in a person's normal life becomes difficult as disrupted activities and social life. Anxiety is one of various emotional and behavioral disorders. Vitasari (2010) mentioned that students with anxiety disorders show passive attitudes in their studies, such as lack of interest in learning, poor performance on examinations, and doing poorly on assignments. Sharma (2017) also believed that anxiety and stress are caused by various existing problems, such as problems at school, financial problems, family problems, and problems around them. High levels of anxiety experienced by a number of adolescents are due to expectations and pressure for achievement that is not realistic from parents, facing evaluation, social comparison, and when experiencing failure (Santrock; 2007) 
Adolescents in formal education, especially at the Senior High School level, need services provided so that learning activities and students' potential can develop optimally. Schools implement character education by providing models, interventions, consistent habituation, and reinforcement (Zurqoni, 2018). Character education has a positive impact on increasing the value of students' characters including religiosity, personality, social attitudes, and competitive attitudes. The character guidance has so far existed in schools, such as in guidance and counseling services (Arifin, 2017). Within the scope of the school, the guidance and counseling services for students will be provided by school counselors. Ebizi (2016) argued that guidance and counseling are important educational tools in shaping an increasingly more positive orientation to children because there are negative ideas or views instilled by their friends in the social environment. Therefore, the school needs a counselor to help children to shape the future of students through guidance and counseling services. Anyi (2017) mentioned that guidance and counseling is illustrated as a process that helps people by facilitating positive growth and adaptation through selfunderstanding. In the Appendix of Regulation of Minister of Education and Culture Number 111 of 2014 , it is stipulated that Guidance and Counseling is a systematic, objective, logical, and sustainable as well as programmed effort carried out by the school counselor to facilitate the development of students/counselees to achieve independence in the form of the ability to understand, accept, direct, making decisions, and realize themselves responsibly s to achieve happiness and prosperity in their life. Putra (2015) explained that the existence of guidance and counseling is required as a support to the learning process and includes the students' adaptation. The duty of school counselors is very significant, so that in carrying it out, it requires a professional attitude from school counselors. In dealing with anxiety, school counselors need to choose the right strategy which suits the students' needs. In the implementation of guidance and counseling, it requires a structured program started from the assessment. The assessment is important to be conducted because by doing it, the program made will be right on target and in accordance with needs. In the National Education Regulation Number 27 of 2008 concerning the academic qualification standards and counselors' competence in professional competence, it is stated that the counselor must master the concepts and praxis of the assessment to understand the condition, needs, and problems of the counselee.

Another study that had been conducted and related to this study states that school counselors provide services related to anxiety but is not structured. Rosmawati (2016) stated that to overcome the anxiety of students at 3th Senior High School of Makassar, school counselors tended to use behavioristic counseling approaches and rational emotive therapy. However, the use of these approaches was still partial, incidental, routine, and had not been implemented systematically. Based on the assessment of the students and the school counselors, the counseling service applied by the school counselors to deal with the students' anxiety at SMA Negeri 3 Makassar had not been maximized so that the expected behavioral change in students was also not optimal. Moreover, Mardiana (2017) stated that the role of school counselors in an effort to reduce the level of students' anxiety when taking the National Final Examination at SMA Nusantara I Tangerang - Banten was included in the moderate category.

Based on the problems that have been explained, this study is considered important. This study aims to determine whether the students' anxiety has been understood and handled by school counselors in schools, especially in Yogyakarta.

\section{Method}

This study was qualitative research with a type of phenomenology. The phenomenon that would be revealed was the number of school counselors who have assessed anxiety and used interpretation in the process of providing guidance and counseling services in the Guidance and Counseling program. The data were collected using interviews and observations. The interviews were carried out by contacting the school counselors one by one. The interview material included the school counselors' knowledge about anxiety assessment, the importance of anxiety assessment, the use of anxiety assessment, the use of interpretation of assessment results, and the program making based on the interpretation. In addition to the interviews, observations related to assessment tools in schools and their use were also made by the researchers.

The participants were school counselors of Senior High Schools in Yogyakarta. The teacher's criteria were school counselors with work experience of more than 2 years and a minimum education of Bachelor's Degree in Guidance and Counseling. The participants were school counselors in 15 schools in Yogyakarta, Indonesia. The researchers explained to the teachers that the interview and observation were 
carried out only for research. All data related to the teachers were coded and kept for its confidentiality. The researchers also conveyed that the results of observation did not affect anything.

The data analysis was carried out using quantitative and qualitative data analysis. The quantitative analysis was done by calculating the percentage of teachers who had conducted anxiety assessments by using data tabulation. An analysis was also carried out regarding the reasons whether the teachers conducted anxiety assessments or did not do it, as well as the obstacles and strategies for anxiety assessments and also the use of the results of anxiety assessments. The data of the interview results were then reduced and presented in tabular form and grouped into sub-themes in small groups. The data analysis was done by determining the relationship between themes which then found understanding which was analyzed by using Bogdan \& Biklen's model (1982).

\section{Results and Discussions}

\section{Information about the school counselors}

The school counselors are educators with academic qualifications of at least a Bachelor's Degree in Education (S-1) in the Guidance and Counseling field and have competence in the Guidance and Counseling field. (The Regulation of Minister of Education and Culture Number 111 of 2014). In this study, the school counselors who are the subjects of the study are at least a Bachelor's Degree in Guidance and Counseling with a minimum working period of two years. The results of the study showed that most were a Bachelor's Degree in Guidance and Counseling and several others were from a Master's Degree in Guidance and Counseling and Bachelor's Degree in Islamic Guidance and Counseling.

\section{The school counselors' knowledge about anxiety assessments}

The school counselors need to have knowledge about anxiety assessments because if there are students experiencing anxiety, the teachers know the services to be provided and can prevent students' anxiety. In this study, data was obtained that most teachers understood about anxiety and ways to detect anxiety. Some teachers already know but some are hesitant in answering. The teachers also know an anxiety tool that can be used in assessing students' anxiety. The results of reduction regarding the school counselors' knowledge about anxiety assessments. Most school counselors understand the importance of assessing students' anxiety.

Next, the school counselors were given questions about the relation of anxiety with aspects of students' achievement. The results of the study showed that most teachers have understood the concept of anxiety and the impact that occurs when a student experiences anxiety. The anxiety that is experienced by students will influence students' achievement because anxiety is associated with students' concentration, psychological comfort, and focus which will ultimately reduce students' achievement.

Table 1. The results of reduction regarding the relation of anxiety with aspects of achievement

\begin{tabular}{|c|c|c|}
\hline No. & Sub-Theme & Relation between sub-themes \\
\hline 1 & Not all anxiety is related to students' achievement & Most teachers have understood \\
\hline 2 & $\mathrm{Ar}$ & iety and the \\
\hline 3 & $\begin{array}{l}\text { thinking space so that it does not } g \\
\text { velop }\end{array}$ & $\begin{array}{l}\text { impact that occurs when a } \\
\text { student experiences anxiety. }\end{array}$ \\
\hline 4 & Anxiety makes students difficult of concentrate & Anxiety that is experienced by \\
\hline 5 & $\begin{array}{l}\text { upt because of anxiety and } \\
\text { r }\end{array}$ & $\begin{array}{l}\text { students will influence students' } \\
\text { achievement because anxiety is }\end{array}$ \\
\hline 6 & Anxiety influer & associated \\
\hline 7 & $\begin{array}{l}\text { Anxiety influences in choosing the priority of what } \\
\text { will be taken }\end{array}$ & $\begin{array}{l}\text { concentration, psychological } \\
\text { comfort, and motivation which }\end{array}$ \\
\hline 8 & Anxiety will reduce one's confidence in reaching achievement & $\begin{array}{l}\text { will ultimately reduce students' } \\
\text { achievement. }\end{array}$ \\
\hline 9 & iety makes students' motivation to learn to be 1 & \\
\hline
\end{tabular}


The importance of anxiety assessment

Anxiety assessment is a way to detect students' anxiety. This is considered important because school counselors need to help students in dealing with their problems. All school counselors understand the importance of anxiety assessment. Teachers can position themselves when they know the level of students' anxiety by providing services as needed. The services can be preventive and curative services.

Examples of school counselors' opinions related to the importance of assessing students' anxiety are as follows

"So if we already understood the extent to which students experience anxiety, we can determine what we should do next ..." (teacher 8)

"There are preventive and curative guidance and counseling services, to determine it, it needs an assistive device. Anxiety measure can be used as an alternative ..." (teacher 14)

Table 2. The results of reduction regarding the benefits of using anxiety assessment

\begin{tabular}{|c|c|c|}
\hline No. & Sub-Theme & Relation between sub-themes \\
\hline 1 & $\begin{array}{l}\text { To find out how much we experience anxiety, then we will } \\
\text { be able to position ourselves more calmly }\end{array}$ & $\begin{array}{l}\text { The school counselors } \\
\text { understand the anxiety }\end{array}$ \\
\hline 2 & As an assistive device to determine students' anxiety levels & $\begin{array}{l}\text { assessment as an assistive device } \\
\text { to determine students' anxiety } \\
\text { levels }\end{array}$ \\
\hline 3 & Helping students deal with anxiety problems that arise & Anxiety assessment is used to \\
\hline 4 & $\begin{array}{l}\text { Detect anxiety in students so that it can be helped by } \\
\text { optimizing guidance and counseling services }\end{array}$ & $\begin{array}{l}\text { help students in dealing with } \\
\text { problems through guidance and }\end{array}$ \\
\hline 5 & $\begin{array}{l}\text { Detect individuals who have excessive anxiety, so they can } \\
\text { be helped }\end{array}$ & counseling services \\
\hline 6 & $\begin{array}{l}\text { Detect if individuals have excessive anxiety or not, if they } \\
\text { experience it, the follow-up must be done by taking a } \\
\text { preventive or curative action for the student }\end{array}$ & $\begin{array}{l}\text { Assessments as prevention of the } \\
\text { impacts of anxiety and solution } \\
\text { when students experience anxiety }\end{array}$ \\
\hline 7 & As a reference medium for anxiety prevention and solution & \\
\hline 8 & To find out what factors can reduce excessive anxiety & $\begin{array}{l}\text { Assessments help the school } \\
\text { counselors in determining factors } \\
\text { to reduce anxiety }\end{array}$ \\
\hline
\end{tabular}

The Use of Anxiety Assessment

In this study, there are many opinions regarding the timing of anxiety assessment. Some think that the time to carry out an anxiety assessment can be done flexibly according to students' needs, considering that not all students experience anxiety. However, there are those who argue that the assessment is carried out programmatically within a predetermined period, for example at the beginning of the semester or the beginning of the year and when they will take the exam.

In terms of the strategies taken to assess students' anxiety, some teachers do not understand. During this time, the teachers use test kits passed from generation to generation and automatic data collection applications so they do not know the specific strategies in dealing with anxiety. The school counselors use a curative approach in assessing anxiety. In addition, some teachers understand the strategy to conduct an anxiety assessment which is understood as a test tool and implementation time. 
Table 3. The results of reduction regarding the use of anxiety assessment

\begin{tabular}{|c|c|c|}
\hline No. & Sub-Theme & Relation between sub-themes \\
\hline 1 & The assessment is carried out when needed & \multirow{6}{*}{$\begin{array}{l}\text { The period to use anxiety } \\
\text { assessment can be done flexibly } \\
\text { according to students' needs }\end{array}$} \\
\hline 2 & $\begin{array}{l}\text { Anxiety assessment is good to carry out at the beginning, } \\
\text { middle, and end of the semester }\end{array}$ & \\
\hline 3 & $\begin{array}{l}\text { The assessment in the form of an interview is carried out } \\
\text { when the children starts to show symptoms of anxiety }\end{array}$ & \\
\hline 4 & When children do not seem eager to learn & \\
\hline 5 & The assessment is carried out when facing a problem & \\
\hline 6 & $\begin{array}{l}\text { When someone will face a situation that is considered } \\
\text { difficult, an assessment can be carried out }\end{array}$ & \\
\hline 7 & $\begin{array}{l}\text { The assessment can be carried out at the beginning of the } \\
\text { academic year }\end{array}$ & \multirow{4}{*}{$\begin{array}{l}\text { According to some school } \\
\text { counselors, the assessment } \\
\text { should be carried out } \\
\text { programmatically within a } \\
\text { predetermined period. }\end{array}$} \\
\hline 8 & $\begin{array}{l}\text { The assessment is carried out at the beginning of the } \\
\text { academic year and before the students take the exam }\end{array}$ & \\
\hline 9 & $\begin{array}{l}\text { The assessment should be carried out routinely, once every } 6 \\
\text { months }\end{array}$ & \\
\hline 10 & Anxiety assessment is carried out at least once a year & \\
\hline
\end{tabular}

Table 4. The results of reduction regarding strategies undertaken to assess anxiety

\begin{tabular}{|c|c|c|}
\hline No. & Sub-Theme & Relation between sub-themes \\
\hline 1 & $\begin{array}{l}\text { If there are students who experience anxiety, the teacher } \\
\text { starts to assess the anxiety with a variety of test and non-test } \\
\text { tools }\end{array}$ & $\begin{array}{l}\text { The school counselors use a } \\
\text { curative approach in assessing } \\
\text { anxiety }\end{array}$ \\
\hline 2 & $\begin{array}{l}\text { When the teacher sees something different in children in } \\
\text { everyday life, the teacher takes non-test assessments, such as } \\
\text { interviews and observations }\end{array}$ & \\
\hline 3 & $\begin{array}{l}\text { Determine the respondent's difficult situation through } \\
\text { interviews and observations, and then give solutions for } \\
\text { anxiety experienced by students }\end{array}$ & \\
\hline 4 & $\begin{array}{l}\text { Give assessments to students and interpret it. The } \\
\text { interpretation is then used for the guidance and counseling } \\
\text { service process }\end{array}$ & \\
\hline 5 & $\begin{array}{l}\text { The assessment is carried out by adapting the assessment } \\
\text { scale questionnaire }\end{array}$ & $\begin{array}{l}\text { The strategy to conduct an } \\
\text { anxiety assessment }\end{array}$ \\
\hline 6 & $\begin{array}{l}\text { The assessment is carried out by using instruments based on } \\
\text { test and non-test assessments through guidance and } \\
\text { counseling services }\end{array}$ & $\begin{array}{l}\text { implementation is understood as } \\
\text { a test tool and implementation } \\
\text { time }\end{array}$ \\
\hline 7 & $\begin{array}{l}\text { Understanding students' anxiety based on observations from } \\
\text { several people }\end{array}$ & \\
\hline 8 & $\begin{array}{l}\text { In addition to tools, interviews are usually used as } \\
\text { identification of students' anxiety }\end{array}$ & \\
\hline 9 & $\begin{array}{l}\text { In addition to using integrated tools, observations are also } \\
\text { used as an assistive device to determine the students' anxiety } \\
\text { levels }\end{array}$ & \\
\hline 10 & $\begin{array}{l}\text { Students' anxiety is assessed periodically and or at the right } \\
\text { time }\end{array}$ & \\
\hline
\end{tabular}


Table 5. The results of reduction of obstacles encountered when making assessments

\begin{tabular}{cll}
\hline No. & \multicolumn{1}{c}{ Sub-Theme } & Relation between sub-themes \\
\hline $\mathbf{1}$ & $\begin{array}{l}\text { Not all students convey that they experience anxiety, so } \\
\text { sometimes the school counselors are confused }\end{array}$ & $\begin{array}{l}\text { Students are less open to the } \\
\text { school counselors }\end{array}$
\end{tabular}

2 Students are still shy in expressing their anxiety sometimes

3 Not every time the respondents face a difficult situation

4 If a lot of instruments are used, the data overlaps, so the analyze should be done from the results of the statements given and it is difficult to do

$5 \quad$ Interpretation of the results of assessment tools and follow-up is difficult to apply in the guidance and counseling program

6 Accuracy of input is very necessary in analyzing students' anxiety

7 Interpretation of results and follow-up is difficult to do

8 Not every day dealing directly with the children

9 There is not enough time to identify students' anxiety one by one

10 The schedule in class to provide classical guidance and interact with students are not too clear

11 The time available is too limited due to the many works delegated to the school counselors
The school counselors have difficulty inserting several instruments in one guidance and counseling program

There are still problems in the interpretation of anxiety assessment results
Time is an obstacle in the process of carrying out assessments due to several things, including the absence of classical time, the amount of responsibility received by the school counselors, and no time to analyze

Human resources available or school counselors in schools do
not have the ability to assess students' anxiety

14 Making questions that represent someone's psychological is very difficult
Competence to take assessments is still lacking Instrument of anxiety is not widely known so that the teachers have not been directed in anxiety assessment

In guidance and counseling, there are many services that must be carried out so that anxiety is equated with other symptoms. Many obstacles faced by school counselors, in which students are less open to the school counselors, difficulties in inserting several instruments in a guidance and counseling program, problems in interpreting anxiety assessment results, time of implementation of anxiety services, assessment competencies that are still lacking and lacking instrument of anxiety that makes the teachers not yet directed in assessing anxiety.

The following are examples of teachers' statements related to implementation obstacles:

"I know anxiety needs treatment, but I'm confused when I need to do it ..." (teacher 13)
"Actually, I don't know how to use anxiety instruments ..." (teacher 14)
"There is no standard instrument, so what should I do? ..." (teacher 5)

The use of assessment interpretation results

The results show that the school counselors use results quickly which is using counseling services (individual and group counseling) because anxiety is considered as something that requires immediate treatment. The interpretation results are used as a basis for making annual programs, and prioritize and classify results. In practice, anxiety is not a priority to deal with sometimes because of the many problems 
faced by students. The results show that (1) school counselor use the results as a determinant of the service to be provided. The service is fast-response because anxiety is considered as something that requires immediate treatment. (2) The interpretation results are used as a basis for making an annual program. (2) The use of interpretation by prioritizing and grouping so that sometimes anxiety is not a priority treatment

The school counselors are educators with academic qualifications of at least a Bachelor's Degree in Education (S-1) in the Guidance and Counseling field and have competence in the Guidance and Counseling field. (The Regulation of Minister of Education and Culture Number 111 of 2014). The results of the study showed that all school counselors were a Bachelor's Degree in Guidance and Counseling. This means that the conditions in the field are in accordance with the regulation of the Ministry of Education and Culture Number 111 of 2014.

Furthermore, in the National Education Regulation Number 27 of 2008 concerning the academic qualification standards and counselors' competence in professional competence, it is stated that the counselor must master the concepts and praxis of the assessment to understand the condition, needs, and problems of the counselee. The American Counseling Association (ACA) code of ethics (2014) in section E explains the counselors' duties in carrying out evaluation, assessment, and interpretation. Moreover, the Council for Accreditation of Counseling and Related Educational Programs (CACREP, 2009 in Susan 2017 ; 3-4) stipulates that eight core areas are required of all students in the counseling accreditation program, one of which is the assessment. A study conducted by Bunu (2016) stated that types of counseling services include helping clients develop polite behavior, helping overcome anxiety, and exploring students' potential. Based on the explanation above, a school counselor should have the ability to use assessments. In fact, not many school counselors have competence in non-test assessments. A thorough evaluation is required regarding the competencies of school counselors, specifically about anxiety assessment.

Anxiety has a negative relationship with several things. Anxiety and motivation level of students have a negative relationship (Widodo, 2017), meaning when anxiety is high, the level of students' motivation is also high. Besides, anxiety has a significant negative relationship with achievement (Swadesi; 2015). Furthermore, Pratama (2018) stated that anxiety has a relationship with the concentration level. A significant negative relationship also occurs between self-confidence and anxiety (Kristanto, 2014). The same thing was expressed by Wahyuni (2014) who revealed that there is a negative relationship between self-confidence and anxiety in public speaking. This is in line as what was conveyed by the school counselors who are the subjects of this study. Anxiety in students disturbs the level of motivation, achievement, concentration, and self-confidence.

Learning assessment functions as a way in the learning process used to determine the score and the reporting so that the overview of learning outcomes implemented by teachers can be known not only by students, but also by all parties (Sudarwan, 2015). In anxiety, assessment is considered important because anxiety needs to be detected immediately so that anxiety disorders can be detected as early as possible and to help counselors or psychologists to assess the anxiety level of their clients (Chrisnawati, 2019).

Many school counselors have not yet taken assessments due to a number of obstacles. The number of teachers who carry out authentic assessments is still small and requires improvement (Kartowagiran, 2016). The obstacle most experienced by school counselors is the limited time they have. This is actually regretted by school counselors, including many schools that do not provide classical time in class. In the Operational Implementation Guidelines of guidance and counseling, it is stated that each school counselor can provide services in the classroom. However, in the 2013 Curriculum, it is mentioned that there is no schedule for guidance and counseling. Actually, the 2013 curriculum aims to improve the quality of human resources and improve the competitiveness of the nation, and in line with the development of science, technology, and art (Retnawati, 2015). However, in relation to guidance and counseling, it still needs improvement. This makes many schools do not provide the schedule for guidance and counseling in the classroom. This can be overcome by school counselors by implementing group guidance and group counseling.

Furthermore, the use of interpretation results also faces obstacles, in which the school counselors cannot use two or more instruments because there is an overlap in the interpretation results. This makes many teachers use integrated assessment because it is considered easier to interpret. There are many anxiety assessments that can be used, such as Fear of Negative Evaluation (FNE) and Social Avoidance 
and Distress (SAD) (Watson and Friend, 1969). Liebowitz's Social Anxiety Scale (LSAS) (1987) and Brief Social Phobia Scale (BSPS) are developed by Davidson, Potts, Richichi, and Ford (1991). In their use, the school counselors must cooperate with psychologists in terms of instrument analysis. This is related to the meaning of assessment in the discipline of psychology carried out in relation to the objectives of pure and applied science (Hidayat, 2011) that the school counselors should not do.

\section{Conclusion}

Based on the results of the analysis, it is known that the school counselors actually understand anxiety and its impacts. However, there are many obstacles found in this study that make the school counselors not carry out anxiety assessment by themselves. In addition, there is no non-test instrument that can be used, such as a scale, which makes the school counselors consider it is enough to use interviews and observations. In this case, a new problem occurs because one school counselor teaches of at least 150 students, which makes not all students monitored.

\section{Acknowledgments}

On this occasion, the researchers would like to thank school counselors of Senior High Schools in Yogyakarta who were willing to become participants of this study. Thank you to the State University of Yogyakarta for providing the opportunity, facilities, and encouragement for writing this journal article.

\section{References}

Anyi E.M.E (2017). The Role of Guidance and Counselling in Effective Teaching and Learning in Schools: The Cameroonian Perspective. International Journal of Educational Technology and Learning, Vol. 1, No. 1, pp. 11-15. DOI: 10.20448/2003.11.11.15

Arifin (2017). Building Character of Students as A Contribution to the Character of the Nation Through Psychological Approach. Jurnal Edukasi Sebelas April. Retrieved from https://jurnal.stkip11april. ac.id/index.php/JESA/article/download/13/11

Bunu, Y.H. (2016). Pemindaian Penerapan Bimbingan dan Konseling dengan Pendekatan Multikultural di SMA. Jurnal Cakrawala Pendidikan. Retrieved from https://journal.uny.ac.id/ index.php/cp/article/view/8892/pdf

Chrisnawati, G. \& Aldino, T. (2019) Aplikasi Pengukuran Tingkat Kecemasan berdasarkan Skala Hars Berbasis Android. Jurnal Teknik Komputer AMIK BSI. Retrieved from https://ejournal.bsi.ac. id/ejurnal/index.php/jtk/article/download/6312/pdf

Davidson, J. R. T., Miner, C. M., De Veaugh-Geiss, J., Tupler, L. A., Colket, J. T., \& Potts, N. L. S. (1997). The Brief Social Phobia Scale: A Psychometric Evaluation. Psychological Medicine, 27(1), 161e166. http://dx.doi.org/10.1017/S0033291796004217

Dawood Eman, et al. (2016). Relationship between Test Anxiety and Academic Achievement among Undergraduate Nursing Students. Journal of Education and Practice IISTE. Retrieved from https://files.eric.ed.gov/fulltext/EJ1089777.pdf

Ebizie Elizabeth Nkechi, et al. (2016) The Role of Guidance and Counselling in Effective Teaching and Learning in Schools. RAY: International Journal of Multidisciplinary Vol. I, No. 2, pp. 36-48. Retrieved from https://www.researchgate.net/publication/324209919_The_role_of_Guidance_and_ Counselling_in_effective_teaching_and_learning_in_schools

Ekstrom, R. B., Elmore, P. B., Schafer, W. D., Trotter, T. V., \& Webster, B. (2004). A Survey Assessment and Evaluation Activities of School Counselors. Professional School Counseling, 8, 24-30

Kartowagiran, B. \& Jaedun, A. (2016). Model Asesmen Autentik untuk Menilai Hasil Belajar Siswa Sekolah Menengah Pertama (SMP): Implementasi Asesmen Autentik di SMP. Jurnal Penelitian dan Evaluasi Pendidikan. Retrieved from https://journal.uny.ac.id/index.php/jpep/article /viewFile/10063/8450

Kristanto, H.P, Sumardjono, P.M., \& Setyorini. (2014). Hubungan antara Kepercayaan Diri dengan Kecemasan dalam Menyusun Proposal Skripsi. Jurnal Satya Widya. Retrieved from: https://ejournal.uksw.edu/satyawidya/article/download/110/98/

Liebowitz, M. R. (1987). Liebowitz Social Anxiety Scale. Modern Problems of Pharmacopsychiatry, 22,141-173.

Mardiana, N. (2017). Peranan Guru Bimbingan dan Konseling dalam Upaya Mengurangi Tingkat Kecemasan Siswa Menghadapi Ujian Nasional. SOSIO-E-KONS, Vol. 9 No. 2, pp. 139-151. 
Retrieved from http:// journal.lppmunindra.ac.id/index.php/sosio_ekons/article/download/ $1945 / 1502$

Ministry of Education and Culture. (2014). Regulation of Minister of Education and Culture Number 111 concerning guidance and counseling in Elementary School and Junior High School. Jakarta: Ministry of Education and Culture.

Ministry of National Education. (2008). National Education Regulation Number 27 concerning the academic qualification standards and counselors' competence. Jakarta: Ministry of National Education.

Niti O. Khemka \& Rajesh R. Rathod (2016). A Study of Academic Anxiety of Secondary School Students. Techno LEARN, Vol. 6: No. 1: p. 31-34. Retrieved from https://www.researchgate.net/publication/ 315479794_A_Study_of_Academic_Anxiety_of_Secondary_School_Students

Putra ARB. (2015). Peran Guru Bimbingan dan Konseling dalam Mengatasi Kecenderungan Perilaku Agresif Peserta Didik di SMK N 2 Palangka Raya Tahun Pelajaran 2014/2015. Jurnal Konseling Gusjigang, Vol. 1 No. 2. Retrieved From https://media.neliti.com/media/publications/107513-IDperan-guru-bimbingan-dan-konseling-dalam.pdf

Rahmawati, A.D, Pratama, A.S.N (2016). Pengaruh Kecemasan terhadap Konsentrasi pada Atlet Renang Petrokimia Gresik. Journal of Sport Science and Education (Jossae). Retrieved from https://journal.unesa.ac.id/index.php/jossae/article/view/2703/2424

Retnawati, H. (2015). Hambatan Guru Matematika Sekolah Menengah Pertama dalam Menerapkan Kurikulum Baru. Jurnal Cakrawala Pendidikan. Retrieved from http://staff.uny. ac.id/sites/default/files/penelitian/heri-retnawati-dr/cp-heri-retnawati-20153-7694-19613-1-pb.pdf

Rosmawati. (2017). Penerapan Layanan Konseling untuk Mengatasi Kecemasan Siswa. Jurnal Konseling Andi Matappa, Vol. 1 No. 1. pp. 39-45. Retrieved from https://media.neliti.com/media/ publications/177170-ID-penerapan-layanan-konseling-untuk-mengat.pdf

Santrock, J. W. (2007). Remaja. 2nd Ed. Translated by Benedictine Widyasinta. Jakarta: Erlangga.

Sharma Rachna. (2017). Relationship Between Academic Anxiety and Mental Health Among Adolescents. Impact: International Journal of Research in Humanities, Arts and Literature (Impact: Ijrhal). Retrieved from https://papers.ssrn.com/sol3/papers.cfm?abstract_id=3090227

Sudarwan, R.E., Retnawati, H. (2015). Pengembangan Perangkat Assessment Pembelajaran Matematika Pokok Bahasan Geometri dan Pengukuran SMP/Mts. Jurnal Riset Pendidikan Matematika. Retrieved from https://journal.uny.ac.id/index.php/jrpm/article/view/7344/6326

Susan C. Whiston. (2017). Principles and Applications of Assessment in Counseling, 5th Ed. United state of America: Cengage Learning.

Swadesi, I.K.I (2015). Hubungan Kecemasan dan Agresivitas Atlet terhadap Prestasi Olahraga Kabupaten Buleleng dalam PORPROV Bali 2011. Jurnal Olahraga Prestasi. Retrieved from: https://journal.uny.ac.id/index.php/jorpres/article/view/10253/7942

Vitasari Prima, et al. (2010). The Relationship between Study Anxiety and Academic Performance among Engineering Students. Procedia Social and Behavioral Sciences, 8 (2010) 490-497. DOI: 10.1016/j.sbspro.2010.12.067

Wahyuni, Sri. (2014). Hubungan Antara Kepercayaan Diri dengan Kecemasan Berbicara di Depan Umum pada Mahasiswa Psikologi. E Journal Psikologi FISIP Unmul. Retrieved from: http://ejournal.psikologi.fisip-unmul.ac.id/site/wpcontent/uploads/2014/04/JURNAL\%20SRI\%20WAHYUNI\%20(04-16-14-04-07-51).pdf

Watson, D., \& Friend, R. (1969). Measurement of Social-Evaluative Anxiety. Journal of Consulting and Clinical Psychology, 33(4), 448e457. DOI: http://dx.doi.org/10.1037/h0027806

Widodo, S.A, Laelasari, Sari, R.M., Nur, I.R.D, \& Putrianti, F.G. (2017). Analisis Faktor Tingkat Kecemasan, Motivasi dan Prestasi Belajar Mahasiswa. Taman Cendekia: Jurnal Pendidikan Ke-SDAn. Retrieved from: http://jurnal.ustjogja.ac.id/index.php/tamancendekia/article/view/1581/706

Wiedemann (2015). Anxiety and Anxiety Disorders. International Encyclopedia of the Social \& Behavioral Sciences, 2nd Ed., Vol. 1. DOI: http://dx.doi.org/10.1016/B978-0-08-097086-8.27006-2

Zurqoni, - , Retnawati, H , Arlinwibowo, J , Apino, E . (2018). Strategy and Implementation of Character Education in Senior High Schools and Vocational High Schools. Journal of Social Studies Education Research, 9 (3), 370-397. Retrieved from https://dergipark.org.tr/en/pub/jsser/issue/43625/534243 